\title{
FLUORESCENCE OF MOLECULAR COMPOSITES THAT CONSIST OF NEMATIC LIQUID CRYSTAL AND MEROCYANINS
}

\author{
M.B. Malynovskyi*, M.M. Sevryukova, Yu.P. Piryatinski \\ Institute of Physics of NASU, 46 Nauky Avenu, Kyiv, 03028, Ukraine \\ *e-mail:malmark@ukr.net \\ Submitted December 9, 2019 \\ Accepted May 07, 2020
}

\begin{abstract}
Background: Considered merocyanine molecules have donor D and acceptor A moieties connected by polymer chain. The conjugated donor $\mathrm{D}$ and acceptor A parts of merocyanine molecules are planar in the ground state. The D- $\pi$-A molecular complexes can change their conformations in an excited state due to cis-trans-conformational transitions. The viscosity of the solvent affects conformational changes, photoluminescence (PL) decay and PL lifetime. Therefore the PL of merocyanine molecules strongly depends on medium in excited and ground states. A nematic liquid crystal was utilized as a solvent for merocyanine molecules since it is characterized by long range order, orientates merocyanine molecules along its axis and is sensitive to external electro-magnetic field. The molecules with conjugated donor D and acceptor A parts are promising for molecular electronics (instruments for recording and processing information), optoelectronics (laser technologies) and biological research (fluorescent probes like prominent thioflavin T), since their PL essentially depends on the nature of the environment.
\end{abstract}

Objectives: The main objective of this paper is to investigate and explain impact of liquid crystal medium on considered molecules. Also influence of molecular conformational changes on their spectral properties is considered.

Materials and Methods: Two types of merocyanine molecules M-1 and M-2 were investigated. The spectral properties of molecules in different organic solvents such as acetonitrile, toluene, glycerol, and in 4-pentyl-4'-cyanobiphenyl (5CB) liquid crystal were compared. Stationary and time-resolved emission spectra of molecular merocyanine solutions were used to investigate conformational changes of molecules. To determine a lifetime of molecular excited states, a technique of Time Correlated Single Photon Counting with picosecond resolution in time was used.

Results: The results indicate that optical properties strongly depend on conformation of conjugated donor- $\pi$-acceptor compounds. A relaxation of dye molecules to the ground state is accompanied by conformational changes. The quantum yield and lifetime of PL increase in more viscous solvents. The liquid crystal made conformational changes of considered molecules in ground and excited states.

Conclusions: Analysis of the results serves as a basis for constructing a theory that explains properties of $D-\pi$-A molecular compounds under optical excitation. The molecular pairs are formed by merocyanine and liquid crystal molecules. The liquid crystal molecule defines conformation of merocyanine molecule in a pair. Moreover, both types of merocyanine molecules in liquid crystal have the same conformation. This hypothesis explains similarities of optical properties of M-1 and M-2 molecules in liquid crystal.

KEY WORDS: photoluminescence; 4-pentyl-4'-cyanobiphenyl (5CB); D- $\pi$-A molecular complexes; merocyanine dyes.

\section{ФЛУОРЕСЦЕНЦЯ МОЛЕКУЛЯРНИХ КОМПОЗИТІВ, ЩО СКЛАДАЮТЬСЯ 3 НЕМАТИЧНОГО РІДКОГО КРИСТАЛУ І МЕРОЦІАНІНІВ М.Б. Малиновський, М.М. Севрюкова, Ю.П. Пирятинський Інститут фізики НАН України, просп. Науки, 46, Київ, 03028, Україна}

\footnotetext{
Актуальність. Розглянуті молекули мероціаніну мають донорні та акцепторні групи з'єднані полімерним ланцюгом. Спряжені донорна D та акцепторна А частини мероціанінових молекул $є$ планарними в основному стані. D- $\pi$-A молекулярні комплекси можуть змінювати свою конформацію в збудженому стані завдяки цис-транс-конформаційним переходам. В'язкість впливає на зміну конформації, а також на загасання фотолюмінесценції (ФЛ) та ії час життя. Через це ФЛ мероціанінових молекул як в основному, так і в збудженому стані сильно залежить від середовища. Нематичний рідкий кристал
}

(C) Malynovskyi M. B., Sevryukova M.M., Piryatinski Yu.P., 2020 
був використаний як розчинник для молекул мероціаніну, оскільки він орієнтує молекули мероціаніну вздовж своєї осі та чутливий до зовнішнього електромагнітного поля. D- $\pi$-A молекулярні комплекси є перспективними для молекулярної електроніки (прилади для запису та обробки інформаціі), оптоелектроніки (лазерні технології), а також для біологічних досліджень (спектральні зонди на зразок відомого тіофлавіну Т) оскільки ФЛ цих молекул суттєво залежить від природи середовища.

Мета роботи. Основна мета даної роботи - дослідити та пояснити вплив рідкокристалічного середовища на розглянуті молекули. А саме: як середовище впливає на конформаційні зміни молекул та на їх спектральні властивості.

Матеріали та методи. Досліджено два типи молекул мероціаніну - M-1 та М-2. Порівнювалися спектральні властивості згаданих молекул в різних органічних розчинниках, таких як ацетонітрил, толуол, гліцерин та рідкий кристал 4-пентил-4'-ціанобіфеніл (5ЦБ). Для дослідження конформаційних змін молекул використовувались стаціонарні та часороздільні спектри випромінювання молекулярних розчинів мероціаніну. Для визначення часу життя молекулярних збуджених станів була використана методика часоскорельованого підрахунку поодиноких фотонів 3 пікосекундною роздільною здатністю у часі.

Результати. Результати показують, що оптичні властивості сильно залежать від конформації спряження донор- $\pi$-акцепторних сполук. У більш в'язких розчинниках збільшуються квантовий вихід і час життя ФЛ. Рідкокристалічне середовище змінює конформацію мероціанінових молекул як в основному, так і в збудженому станах.

Висновки. Аналіз результатів $є$ підгрунтям для побудови теорії, яка пояснює властивості молекулярних D- $\pi$-A сполук після оптичного збудження. Молекули мероціаніну та рідкого кристалу утворюють молекулярні пари. Рідкокристалічна молекула визначає конформацію молекули мероціаніну в парі. Більше того, обидва типи мероціанінових молекул у рідкому кристалі мають однакову конформацію. Це припущення пояснює подібність оптичних властивостей молекул М-1 та М-2 у рідкому кристалі.

КЛЮЧОВІ СЛОВА: фотолюмінесценція; 4-пентил-4'-ціанобіфеніл (5ЦБ); D- $\pi$-А молекулярні комплекси; мероціанінові барвники.

\section{ФЛУОРЕСЦЕНЦИЯ МОЛЕКУЛЯРНЫХ КОМПОЗИТОВ, СОСТОЯЩИХ ИЗ НЕМАТИЧЕСКИХ ЖИДКИХ КРИСТАЛЛОВ И МЕРОЦИАНИНОВ}

М.Б. Малиновский, М.М. Севрюкова, Ю.П. Пирятинский

Институт физики НАН Украины, просп. Науки, 46, Киев, 03028, Украина

Актуальность. Рассмотренные молекулы мероцианина имеют донорные и акцепторные группы, соединенные полимерной цепью. Сопряженные донорные $\mathrm{D}$ и акцепторные $\mathrm{A}$ части мероцианиновых молекул являются планарными в основном состоянии. D- $\pi$-A молекулярные комплексы могут изменять свою конформацию в возбужденном состоянии благодаря цистранс-конформационным переходам. Вязкость влияет на изменение конформации, а также на затухание фотолюминесценции (ФЛ) и ее время жизни. Поэтому ФЛ мероцианиновых молекул, как в основном, так и в возбужденном состоянии, сильно зависит от среды. Нематический жидкий кристалл был использован в качестве растворителя для молекул мероцианина, поскольку он ориентирует молекулы мероцианина вдоль своей оси и чувствителен к внешнему электромагнитному полю. D- $\pi$-А молекулярные комплексы являются перспективными для молекулярной электроники (приборы для записи и обработки информации), оптоэлектроники (лазерные технологии), а также для биологических исследований (спектральные зонды, например известный тиофлавин Т) поскольку ФЛ этих молекул существенно зависит от природы среды.

Цель работы. Основная цель данной работы - исследовать и объяснить влияние жидкокристаллической среды на рассматриваемые молекулы. А именно: как среда влияет на конформационные изменения молекул и на их спектральные свойства.

Материалы и методы. Исследовано два типа молекул мероцианина - M-1 и М-2. Сравнивались спектральные свойства упомянутых молекул в различных органических растворителях, таких как ацетонитрил, толуол, глицерин и жидкий кристалл 5СВ. Для исследования конформационных изменений молекул использовались стационарные и разделенные во времени спектры излучения молекулярных растворов мероцианина. Для определения времени жизни возбужденных состояний молекул была использована методика скоррелированного во времени подсчета единичных фотонов с пикосекундных разрешением во времени.

Результаты. Результаты показывают, что оптические свойства сильно зависят от конформации сопряжения донор-л-акцепторных соединений. В более вязких растворителях увеличивается 
Fluorescence of molecular composites that consist of nematic liquid crystal...

квантовый выход и время жизни ФЛ. Жидкокристаллическая среда изменяет конформацию мероцианиновых молекул как в основном, так и в возбужденном состояниях.

Выводы. Анализ результатов служит основой для построения теории, объясняющей свойства молекулярных D- $\pi$-A соединений после оптического возбуждения. Молекулы мероцианина и жидкого кристалла образуют молекулярные пары. В паре жидкокристаллическая молекула определяет конформацию молекулы мероцианина. Более того, оба типа мероцианиновых молекул в жидком кристалле имеют одинаковую конформацию. Это предположение объясняет сходство оптических свойств молекул М-1 и М-2 в жидком кристалле.

КЛЮЧЕВЫЕ СЛОВА: фотолюминесценция; 4-пентил-4'-цианобифенил (5CB); D-л-А молекулярные комплексы; мероцианиновые красители.

The structure of merocyanine molecules may be either planar or twisted [1]. The photoluminescence (PL) of D- $\pi$-A complexes strongly depends on molecular structure. We may investigate their properties in different shapes by changing medium, since viscosity of solvent affects structure of merocyanine molecules [2,3]. Considering a structure of liquid crystals (LC) we assumed that it is possible to utilize them as the elastic molecular mediums. Moreover, liquid crystals might be used as the template for orientational ordering of luminescent organic molecules placed in them $[4,5]$. The interaction of molecular D- $\pi-A$ complexes based on merocyanine dyes with LC template produces interesting phenomena: formation of merocyanine and LC molecular pairs, conformational specification of D- $\pi-\mathrm{A}$ complexes and delaying of conformational changes of $\mathrm{D}-\pi-\mathrm{A}$ complexes during their relaxation from the excited state. Merocyanine and LC molecular structures form a nanocomposite material that is easily controlled by external electric and magnetic fields and, thus, can be used in electro-optics and nonlinear optics.

We are interested in the conformation-dependent optical properties of merocyanine dyes. For this reason the optical spectra properties of the merocyanine dyes in the 4-pentyl-4'cyanobiphenyl (5CB) liquid crystal were compared with their spectral properties in organic solvents of various viscosities - acetonitrile, glycerol, and polarities - acetonitrile, toluene. The optical investigation techniques, such as stationary photoluminescence, time-resolved emission spectra were used to analyze kinetics of conformational transformations.

\section{EXPERIMENTAL SECTION}

\subsection{Samples preparation}

The merocyanine molecules are supramolecular D- $\pi$-A complexes (Fig. 1) M-1 (2-(3-\{2[4-(dimethylamino)phenyl]vinyl $\}-5,5$-dimethylcyclohex-2-en-1-ylidene)malononitrile) and M-2 (2-\{5,5-dimethyl-3-[2-(2,3,6,7-tetrahydro-1H,5H-pyrido[3,2,1-ij]quinolin-9-yl)vinyl] cyclohex-2-en-1-ylidene malononitrile). These molecules are utilized as the organic dyes.
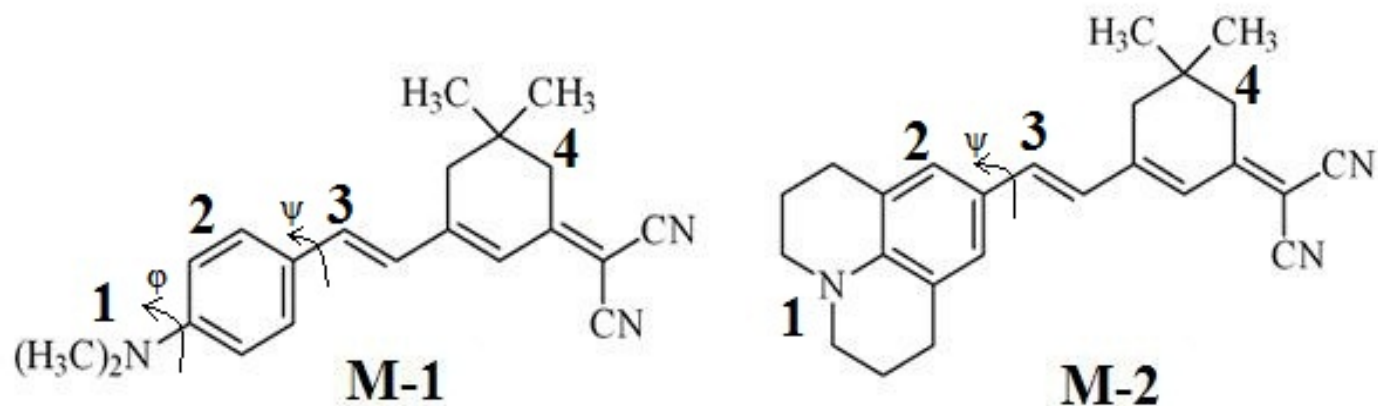

Fig. 1. Structural formulas of merocyanine molecules. 1 - dimethylaminogroup, 2 - benzene ring, $3-\pi$-electron system of metin groups (carbon chain), $4-$ malodinitrile residue, $\varphi$ and $\psi$-torsion angles. 
The M-1 and M-2 molecules consist of dimethylamino group, benzene ring, $\pi$-electron system of metin groups (carbon chain) and malodinitrile residue. The conformation of M-1 molecule depends on two torsion angles $\varphi$ and $\psi$. The angle $\varphi$ specifies the orientation of the dimethylamino group relative to the benzene ring. The angle $\psi$ defines the orientation of the benzene ring relative to the carbon chain and malodinitrile residue. The energy barrier of $N\left(\mathrm{CH}_{3}\right)_{2}$ rotation relative to the benzene ring equals to $2800 \mathrm{~cm}^{-1}$ and energy barrier of benzene ring with dimethylamino group rotation relative to the carbon chain equals to 700 $1000 \mathrm{~cm}^{-1}$ [2]. The M-2 molecule consists of the same elements, but rotation of $\mathrm{N}\left(\mathrm{CH}_{3}\right)_{2}$ is blocked bytrimethylene bridges, thus, $\varphi=0^{\circ}$. Synthesis of M-1 and M-2 is described in the articles $[6,7]$.

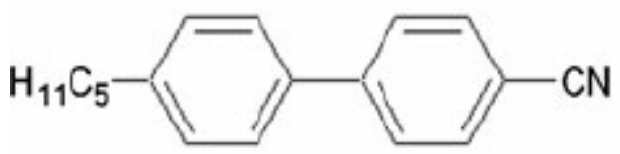

Fig. 2. Structural formula of liquid crystal4-pentyl-4'-cyanobiphenyl (5CB).

Liquid crystal 4-pentyl-4'-cyanobiphenyl (Fig. 2) was used as a solvent for D- $\pi$-A complexes. The LC was provided by Merck. $5 \mathrm{CB} \mathrm{LC}$ is at nematic phase at $22.5-35.5^{\circ} \mathrm{C}$. A crystalline phase is below $22.5^{\circ} \mathrm{C}$ and an isotropic phase is above $35.5^{\circ} \mathrm{C}$. The supramolecular D- $\pi$-A complexes were provided by Institute of Organic Chemistry, NAS of Ukraine. Samples were prepared by mixing the supramolecular complexes with 5CB LC. Since merocyanine molecules were dissolved in chloroform by manufacturer, samples were keeping warm at $80^{\circ} \mathrm{C}$ to evaporate chloroform. To measure the $\mathrm{PL}$ of merocyanine dyes in $5 \mathrm{CB}$ template, we used optical quartz cuvettes $100 \mu \mathrm{m}$ thick. The concentration of merocyanine molecules was $5 \cdot 10^{-5}$ per LC molecule. The acetonitrile (low viscosity) and the glycerol (high viscosity) were also used as the solvents for M-1 and M-2 molecules.

\subsection{Equipment}

The optical density spectra were measured by Lambda 1050 UV/VIS/NIR (Perkin Elmer). The stationary PL spectra were measured by USB2000 + UV-VIS-ES spectrometer through optical fiber $600 \mu \mathrm{m}$ diameter. The light-emitting diodes (LED) LLS-270, 385, 390 (Ocean Optics B.V.) were used to excite stationary PL. A semiconductor laser EPL-405 with $\lambda_{e x}=405 \mathrm{~nm}$ and pulse duration $40 \mathrm{ps}$ was used to excite non-stationary PL. The frequency of laser pulses could be changed from $20 \mathrm{MHz}$ to $10 \mathrm{KHz}$. A LED with $\lambda_{\text {ex }}=255 \mathrm{~nm}$ and pulse duration $900 p s$ was used to excite PL in UV range. The lifetimes of excited states $\tau$ were measured by time-correlated single-photon counting (TCSPC) technique. The time dependence of the PL was approximated by the expression:

$$
I(t)=I R F \cdot \sum_{i=1}^{n} A_{i} \exp \left(-\frac{t}{\tau_{i}}\right),
$$

IRF — impulse response function;

$i$ - a number;

$\tau_{i}$ - the lifetimes of excited states;

$A_{i}$ - the pre-exponential factors;

$t$ - a time.

A certified colloidal solution was used to determine IRF. The time-resolved emission spectra (TRES) were measured by Life Spec II spectrofluorometer (Edinburgh Instruments Ltd, UK). 


\section{RESULTS AND DISCUSSION}

\subsection{Optical properties of M-1 and M-2 molecules in acetonitrile}

The optical density and PL spectra of M-1 and M-2 molecules in acetonitrile (highly polar solvent) are shown in Fig. 3. The concentration of each solution is $c=2 \cdot 10^{-6} \mathrm{~mol} / \mathrm{l}$. The bands in PL spectra with $\lambda_{\max }<450 \mathrm{~nm}$ are caused by the electronic transitions from the local electronic states of dimethylamino group. The PL bands with $\lambda_{\max }>450 \mathrm{~nm}$ are necessitated by first $\operatorname{singlet}\left(S_{0} \rightarrow S_{1}\right) \pi \pi^{*}$ electronic transition that strongly depends on a carbon chain conformation [8]. The absorption spectral bands with $\lambda_{\max }=498 \mathrm{~nm}$ and $\lambda_{\max }=545 \mathrm{~nm}$ are also caused by the first singlet electronic transition. The absorption bands of M-2 solution are shifted to long-wavelength region by $47 \mathrm{~nm}$ more than the absorption bands of M-1 solution. Stokes shift in Fig. 3 is equal to $182 \mathrm{~nm}\left(5374 \mathrm{~cm}^{-1}\right)$. An investigation of solution M-2 in acetonitrile was described in paper [8].

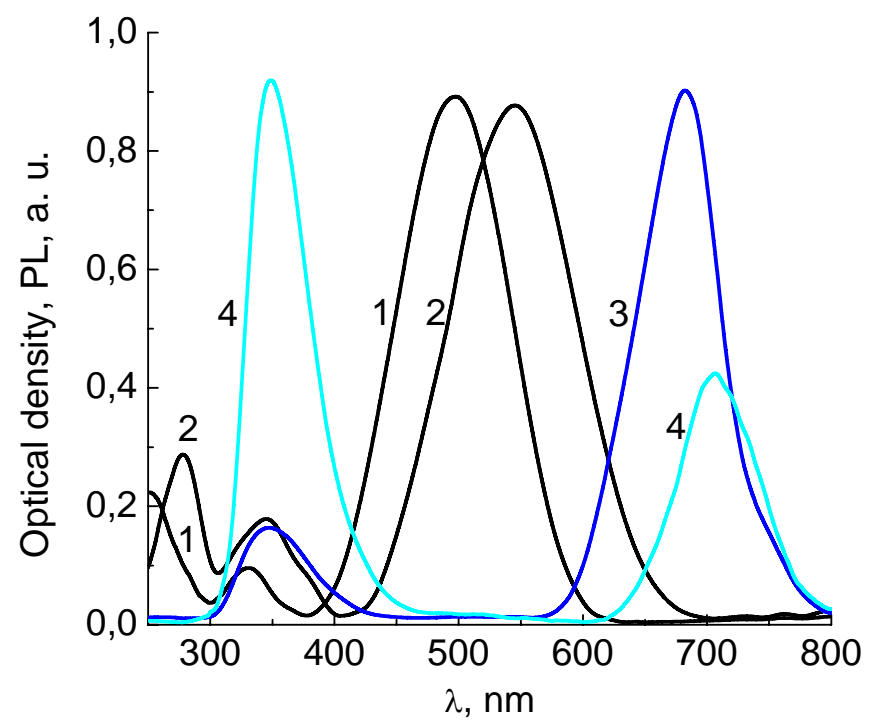

Fig. 3. Optical density (curves 1,2) and PL (curves 3, 4) spectra of molecular solutions M-1 (curves 1, 3) and M-2 (curves 2, 4) in acetonitrile at $300 \mathrm{~K} . \lambda_{\mathrm{ex}}=255 \mathrm{~nm}$.

The lifetime of PL is an average time of remaining molecules in an excited state. Determination of the PL lifetime allows us to find energy transfer speed, the reaction rate in an excited state and information about interaction of excited molecule and medium. The calculations prove that conjugated parts (dimethylamino groups) of M-1 and M-2 molecules are planar, that is typically for $\pi$-electron systems [9]. The conformational changes of $\mathrm{M}-1$ and M-2 molecules in an excited state lead to decrease of PL lifetime and quantum yield. The kinetic curves of PL decay of M-1 (a, c) and M-2 (b, d) [8] molecules solved in acetonitrile at $296 \mathrm{~K}(\mathrm{a}, \mathrm{b})$ and $4.2 \mathrm{~K}(\mathrm{c}, \mathrm{d})$ are shown in Fig. 4.

The PL decay of organic dyes in acetonitrile solvent at room temperature $(296 \mathrm{~K})$ is monoexponential with lifetime in subnanosecond range. The PL decay at low temperature $(4.2 \mathrm{~K})$ is well interpolated by biexponential function (2) with lifetimes in picosecond and nanosecond range.

$$
I_{P L}(t)=A_{1} e^{-t / \tau_{1}}+A_{2} e^{-t / \tau_{2}}
$$

The PL lifetimes of different wavelength were determined from PL decay curves and are shown in Table 1 . The date set of M-2 was kindly provided by authors of article [8]. 


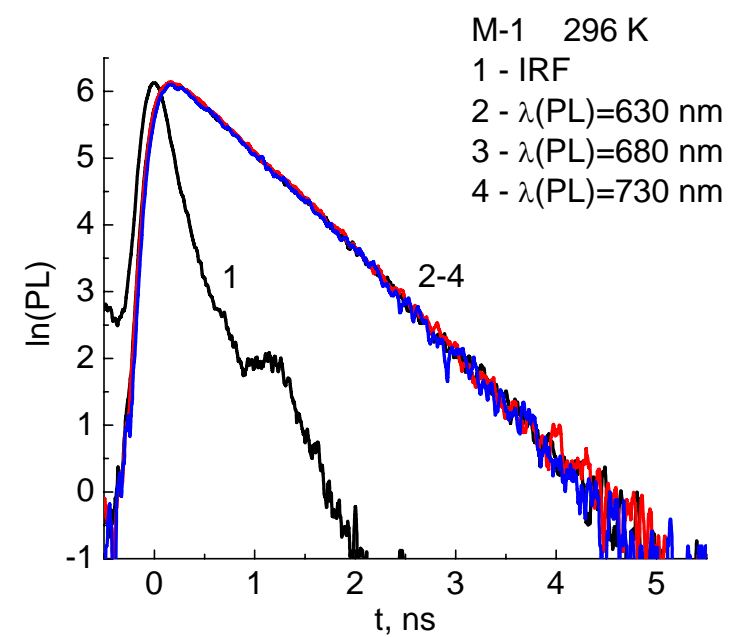

a

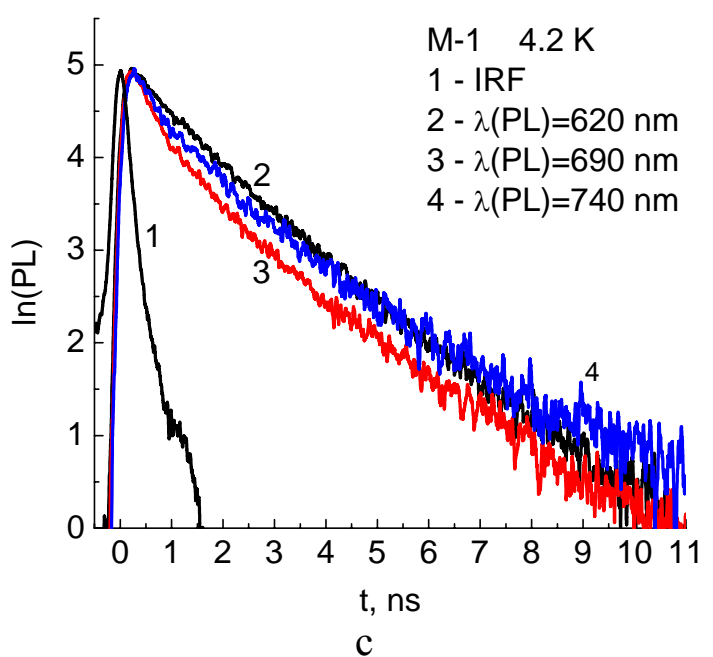

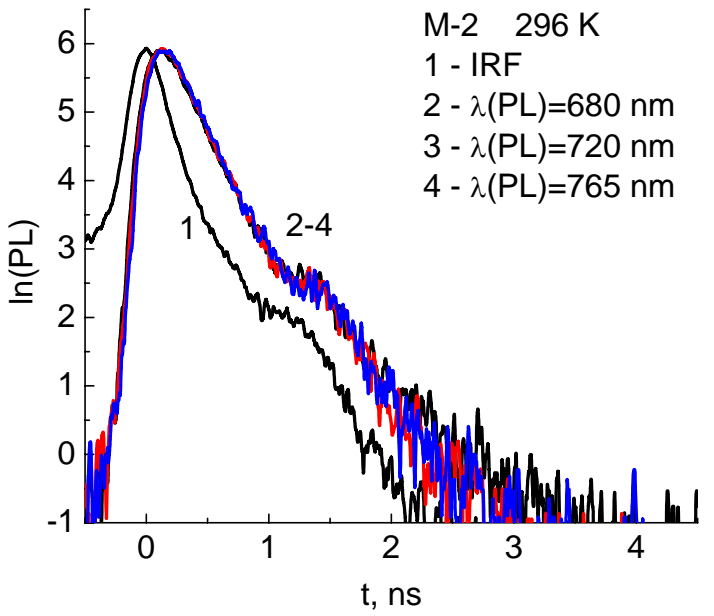

b

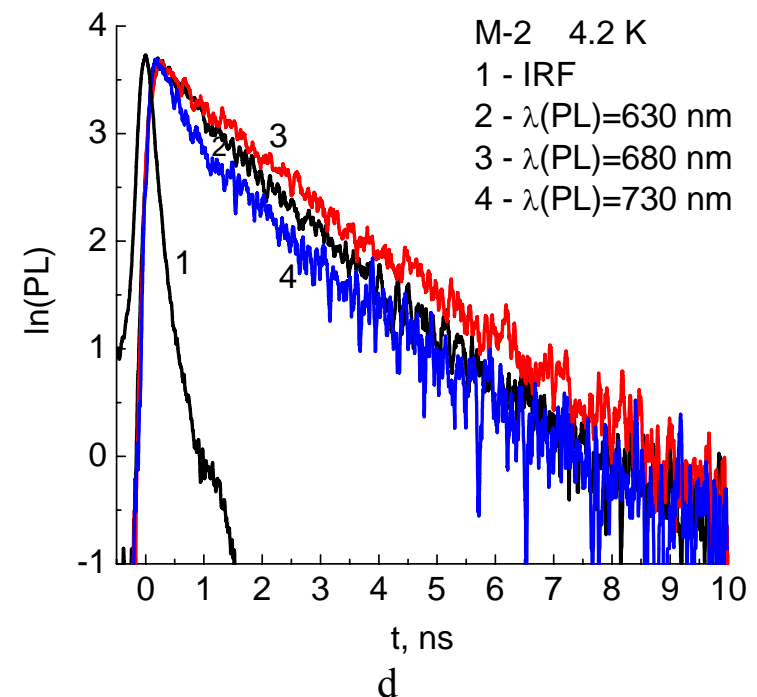

Fig. 4. Kinetic PL decay curves of molecular solutions M-1 (a, c) and M-2 (b, d) in acetonitrile at 296 K (a, b) and at $4.2 \mathrm{~K}(\mathrm{~b}, \mathrm{~d}) . \lambda_{e x}=405 \mathrm{~nm}$.

Table 1. PL lifetimes of different wavelengths of molecular solutions M-1 and M-2 in acetonitrile.

The contribution of each of the decay components $\tau_{1}$ and $\tau_{2}$ is determined as a percentage. $\chi^{2}-$ standard deviation of lifetime.

\begin{tabular}{|l|l|l|l|l|}
\hline & $\lambda_{P L}, \mathrm{~nm}$ & $\tau_{1}, \mathrm{ps}$ & $\tau_{2}, \mathrm{ps}$ & $\chi^{2}$ \\
\hline \multirow{3}{*}{$\mathrm{M}-2, \mathrm{~T}=296 \mathrm{~K}$} & 680 & 135 & & 1,574 \\
\cline { 2 - 5 } & 765 & 135 & & 1,680 \\
\hline \multirow{3}{*}{$\mathrm{M}-2, \mathrm{~T}=4,2 \mathrm{~K}$} & 630 & $115(10 \%)$ & $1700(90 \%)$ & 1,184 \\
\cline { 2 - 5 } & 680 & $129(7 \%)$ & $2096(93 \%)$ & 1,201 \\
\cline { 2 - 5 } & 730 & $110(20 \%)$ & $1400(80 \%)$ & 1,243 \\
\hline \multirow{3}{*}{$\mathrm{M}-1, \mathrm{~T}=296 \mathrm{~K}$} & 630 & 520 & & 1,280 \\
\cline { 2 - 5 } & 680 & 520 & & 1,236 \\
\hline \multirow{3}{*}{$\mathrm{M}-1, \mathrm{~T}=4,2 \mathrm{~K}$} & 620 & $268(13 \%)$ & $1980(87 \%)$ & 1,141 \\
\cline { 2 - 5 } & 690 & $220(27 \%)$ & $1940(73 \%)$ & 1,740 \\
\cline { 2 - 5 } & 740 & $216(16 \%)$ & $2100(84 \%)$ & 1,120 \\
\hline
\end{tabular}

The molecules M-1 and M-2 in acetonitrile solvent have a very low quantum yield at room temperature. Such a low quantum PL yield for molecules is explained by its torsional relaxation (change in angle $\psi$ upwards to $90^{\circ}$ ) in the excited state [7]. Torsional relaxation causes a state that is characterized by almost zero value of the oscillator force and is non- 
Fluorescence of molecular composites that consist of nematic liquid crystal...

fluorescent. The transition from fluorescent to non-fluorescent state is delayed by the viscosity of the medium and is the main reason for the insignificant quantum yield in low viscous solvents. However, quantum yield is high in acetonitrile at low temperature because torsional relaxations are frozen.

\subsection{Optical properties of M-1 and M-2 molecules in toluene}

The stationary PL spectra of M-1 and M-2 molecules in toluene (weakly polar solvent) are shown in Fig. 5 a. The emission of the first $\left(S_{1} \rightarrow S_{0}\right)$ electronic transition is shown in this region. The excitation wavelength $\lambda_{e x}=337.1 \mathrm{~nm}$ was emitted by a nitrogen laser. It is worth mentioning that the PL quantum yields of merocyanine solutions are higher at low temperature than at room temperature. The PL spectral structure and bands maxima of investigated samples in toluene do not depend significantly on temperature changes (from $296 \mathrm{~K}$ to $4.2 \mathrm{~K}$ ). The $\mathrm{PL}$ spectrum of $\mathrm{M}-1$ in toluene at $4.2 \mathrm{~K}$ consists of $589 \mathrm{~nm}$ and $625 \mathrm{~nm}$ bands with shoulder at $660 \mathrm{~nm}$. The band at $625 \mathrm{~nm}$ and $680 \mathrm{~nm}$ shoulder is typical for PL of M-2in toluene at $4.2 \mathrm{~K}$. The spectra of M-2 in toluene were also investigated in paper [8].

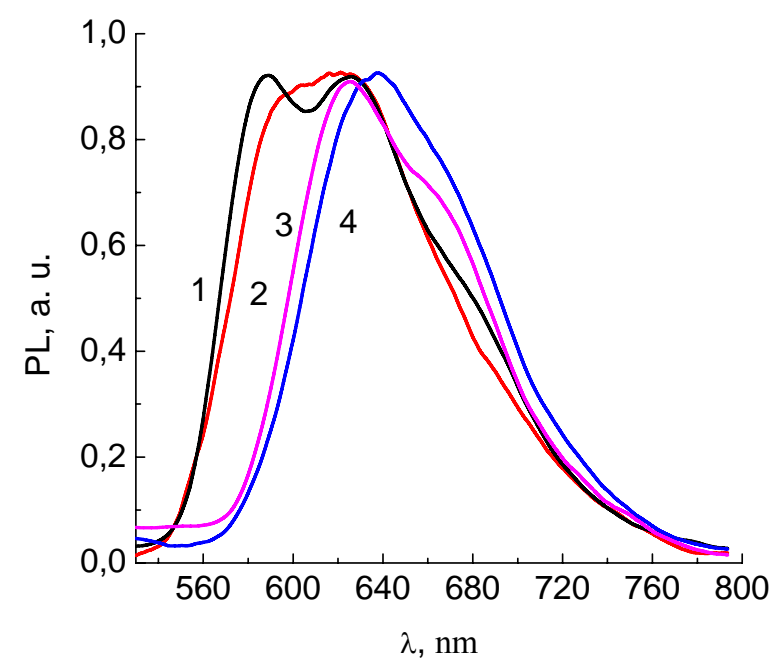

a

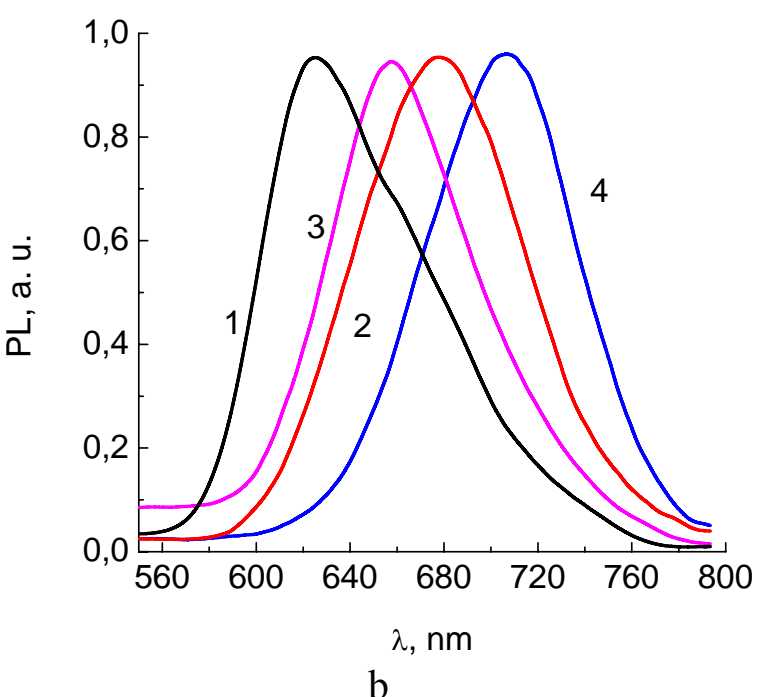

b

Fig. 5. PL spectra of molecular solutions M-1 (curves 1, 2) and M-2 (curves 3, 4) in toluene (a) and acetonitrile (b) at $296 \mathrm{~K}$ (curves 2,4 ) and $4.2 \mathrm{~K}$ (curves 1,3 ). $\lambda_{\text {ex }}=337.1 \mathrm{~nm}$.

As it is shown in Fig. 5 a, b, the solvent polarity significantly affects PL of samples in the region of first electronic transition at room temperature. Changes of polarity of the medium induce conformational transformation of carbon chain [10] and vary electric dipole moment of merocyanine molecules in exited state. It is known that the PL of many dye solutions does not depend on polarity of solvent at low temperature, because there are no solvation processes. But in Fig. $5 \mathrm{a}, \mathrm{b}$ it is shown that the PL depends on polarity even at $4.2 \mathrm{~K}$ [8]. The common for both solvents is short-wave shift of the PL bands maxima at low temperature compared to bands maxima at room temperature.

\subsection{Optical properties of M-1 and M-2 molecules in glycerol}

The PL spectra of molecular solutions M-1 and M-2 in glycerol with the bands maxima at $697 \mathrm{~nm}$ and $710 \mathrm{~nm}$ respectively are shown in Fig. 6. 


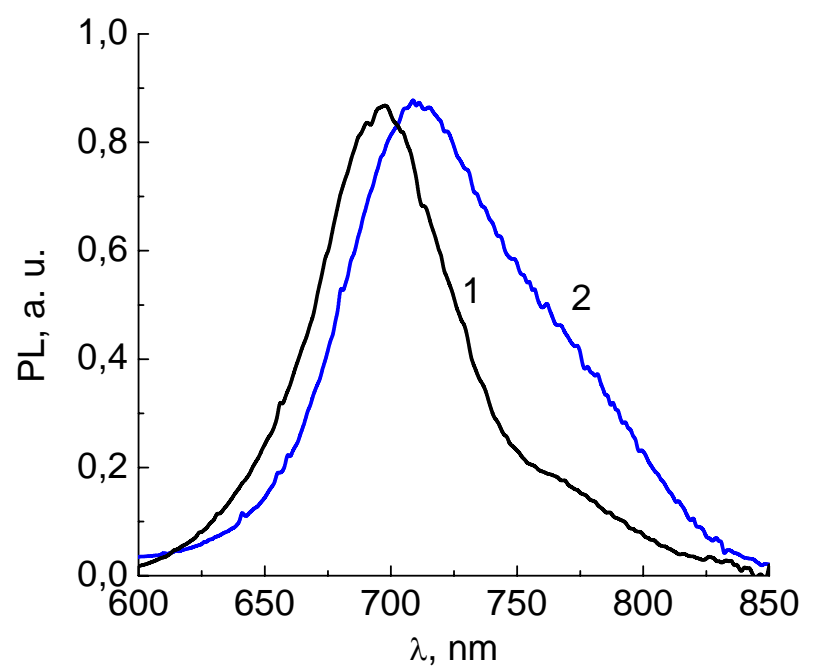

Fig. 6. PL spectra of molecular solutions M-1 (1), M-2 (2) in glycerol at $296 \mathrm{~K}$. $\lambda_{\text {ex }}=405 \mathrm{~nm}$.

The PL bands maxima of molecular solutions M-1 and M-2 in glycerol are slightly (3-4 nm) shifted to long-wave region compared to acetonitrile.

The kinetic of PL decay of M-1 (a) and M-2 (b) molecular solutions in glycerol for many wavelengths is shown in Fig. 7. The kinetic curves for these samples are biexponential.

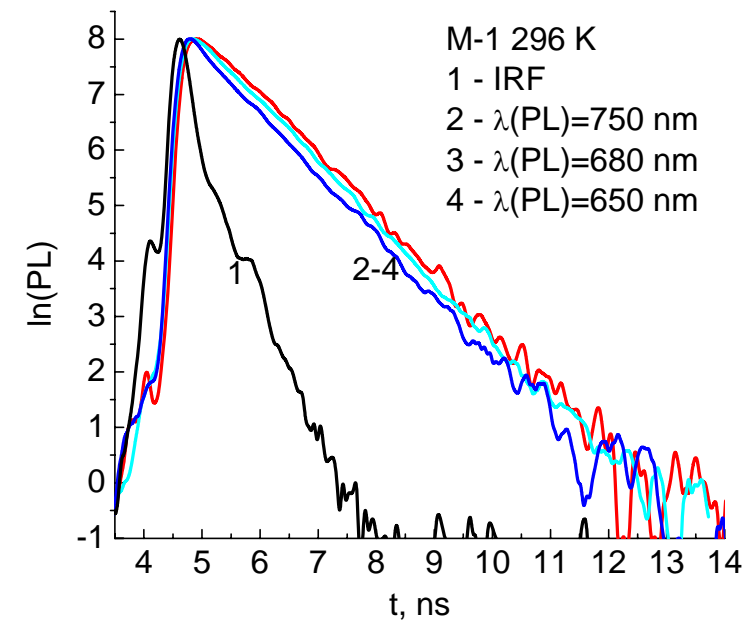

a

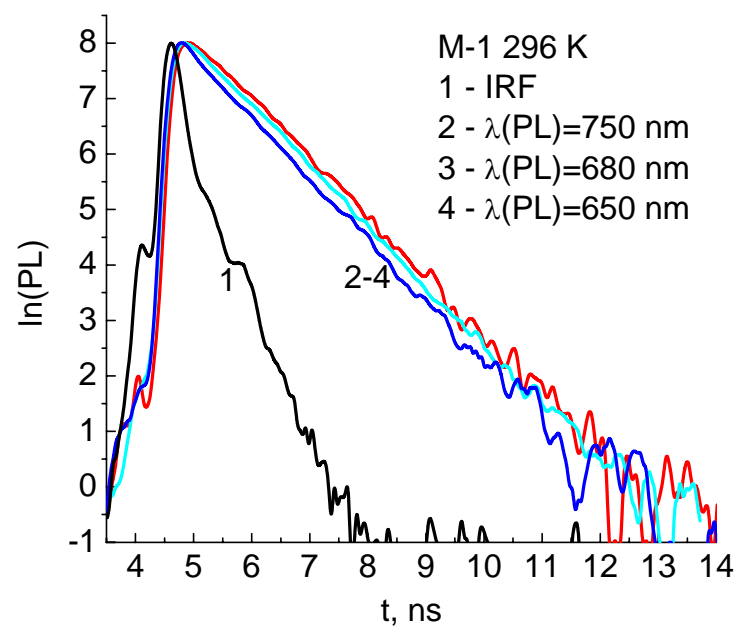

b

Fig. 7. Kinetic PL decay curves of molecular solutions M-1 (a) and M-2 (b) in glycerol at $296 \mathrm{~K} . \lambda_{e x}=$ $405 \mathrm{~nm}$.

The PL lifetimes of supramolecular D- $\pi$-A complexes solved in glycerol at room temperature are shown in Table 2. These lifetimes are much longer compared to PL lifetimes of M-1 and M-2 in acetonitrile at $296 \mathrm{~K}$.

In contrast to acetonitrile, glycerol is very viscous solvent that is why torsion relaxations are delayed there, thus, quantum yield increases and the PL lifetime prolongs. 
Fluorescence of molecular composites that consist of nematic liquid crystal...

Table 2. PL lifetimes of different wavelengths of molecular solutions M-1 and M-2 in glycerol.

The contribution of each of the decay components $\tau_{1}$ and $\tau_{2}$ is determined as a percentage. $\chi^{2}$ - standard deviation of lifetime.

\begin{tabular}{|l|l|l|l|l|}
\hline & $\lambda_{\mathrm{PL}}, \mathrm{nm}$ & $\tau_{1}, \mathrm{ps}$ & $\tau_{2}, \mathrm{ps}$ & $\chi^{2}$ \\
\cline { 2 - 5 } $\mathrm{M}-2, \mathrm{~T}=296 \mathrm{~K}$ & 700 & $120(35 \%)$ & $850(65 \%)$ & 1.146 \\
\cline { 2 - 5 } & 760 & $160(25 \%)$ & $770(75 \%)$ & 1.020 \\
\cline { 2 - 5 } $\mathrm{M}-1, \mathrm{~T}=296 \mathrm{~K}$ & 640 & $120(22 \%)$ & $1350(78 \%)$ & 1.100 \\
\cline { 2 - 5 } & 680 & & 1080 & 1.460 \\
\cline { 2 - 5 } & 700 & $160(11 \%)$ & $1340(89 \%)$ & 1.080 \\
\hline
\end{tabular}

\subsection{Optical properties of $M-1$ and $M-2$ molecules in liquid crystal $5 C B$}

The PL spectra and kinetic PL decay curves of molecular solutions M-1 and M-2 in the liquid crystal (LC) 5CB are shown in Fig. 8 and Fig. 9 respectively. The benzene rings of $5 \mathrm{CB}$ molecule are non-coplanar in the ground state and coplanar in an excited state. The angle between benzene rings is in range $0^{\circ}-30^{\circ}[11,12]$. The LC molecules emit in both conformations. The molecules of cyanobiphenyl in the nematic phase form pre-dimeric centrosymmetric structures with the arrangement of cyanobiphenyl molecules on a head-totail rule [13]. The pre-dimeric pairs aresandwich-type complexes that are usually formed from non-coplanar 5CB molecules. Due to steric restrictions, the molecules in such pairs are at a significant distance from each other. Since the distances between molecules are shorter in an excited state $[12,14]$, interaction between molecules increases and pre-dimeric pairs become excimers.

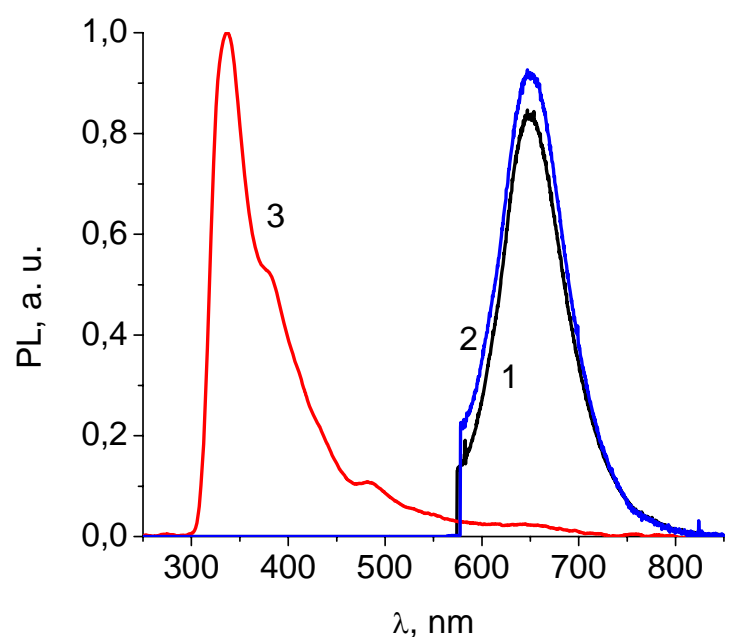

Fig. 8 a. PL spectra of molecular solutions $\mathrm{M}-1$ (curve 1), M-2 (curves 2, 3) in the 5CBLC at $296 \mathrm{~K}$. $\lambda_{e x}=385 \mathrm{~nm}$ (curve 1), $\lambda_{e x}=530 \mathrm{~nm}$ (curve 2), $\lambda_{\text {ex }}=270 \mathrm{~nm}$ (curve 3 ).

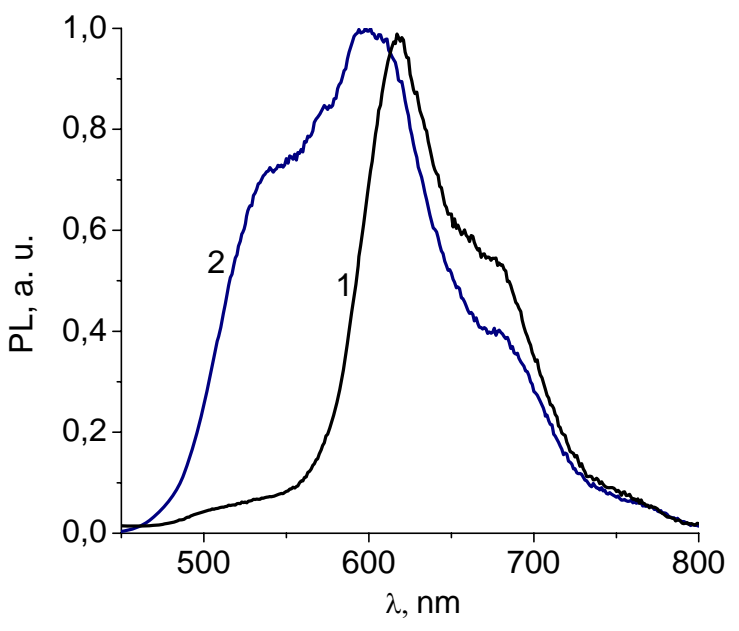

Fig. 8 b. PL spectra of molecular solutions $\mathrm{M}-1$ (curve 1), M-2 (curve 2) in the 5CBLC at $4.2 \mathrm{~K}$. $\lambda_{\text {ex }}=405 \mathrm{~nm}$ (curves 1,2).

It is known that the classical excimers are characterized by the PL band at $422 \mathrm{~nm}$ with long lifetime $(\mathrm{t}=12 \mathrm{~ns})$ at room temperature [12]. Since it is seen quenching of excimer PL of 5CB in Fig. 8 a (curve 3), we propose that the dissolved merocyanine dye molecules displace one of the cyanobiphenyl molecules in the pre-dimeric pairs and new pairs of merocyanine and LC molecules are formed. The PL spectra bands at $337 \mathrm{~nm}$ and $375 \mathrm{~nm}$ in Fig. 8 a (curve 3 ) might be emitted by monomers and dimers of LC $[12,14]$. Considering the similarities of spectral shape in range $\lambda_{P L}>600 \mathrm{~nm}$ (Fig. $8 \mathrm{a}, \mathrm{b}$ ) we assume that the M-1 and M-2 molecules adjust to conformation of 5CB LC molecules. The liquid crystal, as a template 
for the molecular D- $\pi$-A complexes, specifies their orientation and can lead to some conformational changes in the structure of merocyanine dyes in the ground state, but the significant torsional conformational changes in the excited state are not allowed due to considerable elasticity of the LC.

Time-resolved emission spectra (TRES) of M-1 and M-2 in 5CB LC at $4.2 \mathrm{~K}$ are shown in Fig. 10. The map of TRES is shown in Fig. 11.

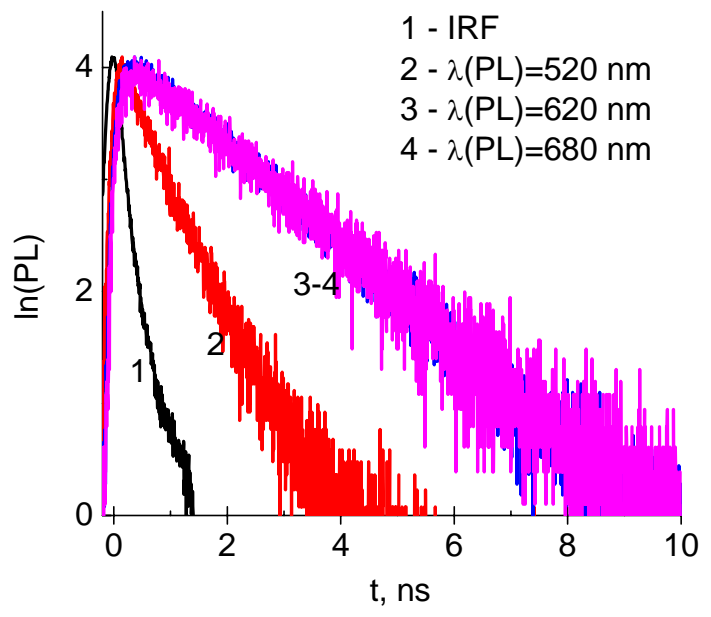

a

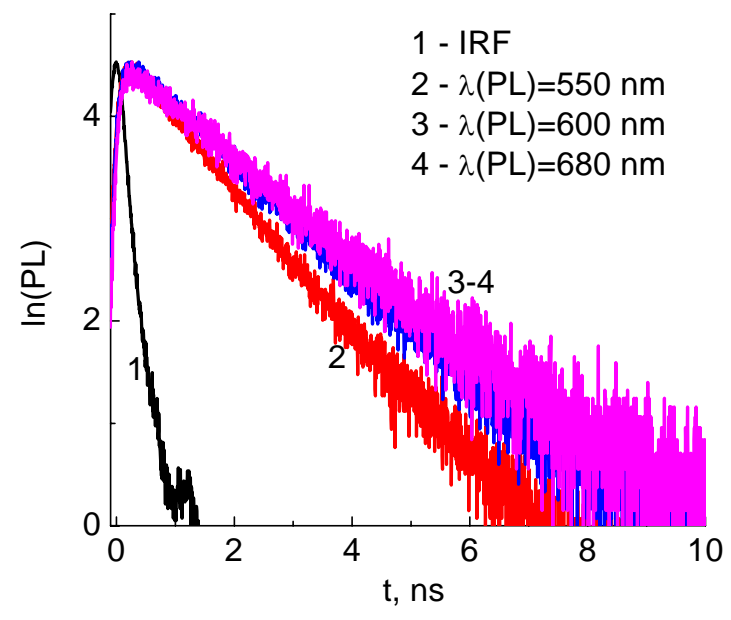

b

Fig. 9. Kinetic PL decay curves of molecular solutions M-1 (a) and M-2 (b) in 5CB LC at $4.2 \mathrm{~K}$. $\lambda_{\text {ex }}=405 \mathrm{~nm}$.

Table 3. PL lifetimes of different wavelengths of molecular solutions M-1 and M-2 in 5CB LC.

The contribution of each of the decay components $\tau_{1}$ and $\tau_{2}$ is determined as a percentage. $\chi^{2}$ - standard deviation of lifetime.

\begin{tabular}{|l|l|l|l|l|}
\hline & $\lambda, \mathrm{nm}$ & $\tau_{1}, \mathrm{ps}$ & $\tau_{2}, \mathrm{ps}$ & $\chi^{2}$ \\
\hline \multirow{4}{*}{$\mathrm{M}-2, \mathrm{~T}=4.2 \mathrm{~K}$} & 550 & $384(12 \%)$ & $1482(88 \%)$ & 1.216 \\
\cline { 2 - 5 } & 600 & $551(12 \%)$ & $1874(88 \%)$ & 1.131 \\
\cline { 2 - 5 } & 680 & $142(5 \%)$ & $2023(95 \%)$ & 1.153 \\
\hline \multirow{3}{*}{$\mathrm{M}-1, \mathrm{~T}=4.2 \mathrm{~K}$} & 520 & $162(32 \%)$ & $844(68 \%)$ & 1.142 \\
\cline { 2 - 5 } & 620 & $80(5 \%)$ & $2096(95 \%)$ & 1.442 \\
\cline { 2 - 5 } & 680 & & 2167 & 1.103 \\
\hline
\end{tabular}
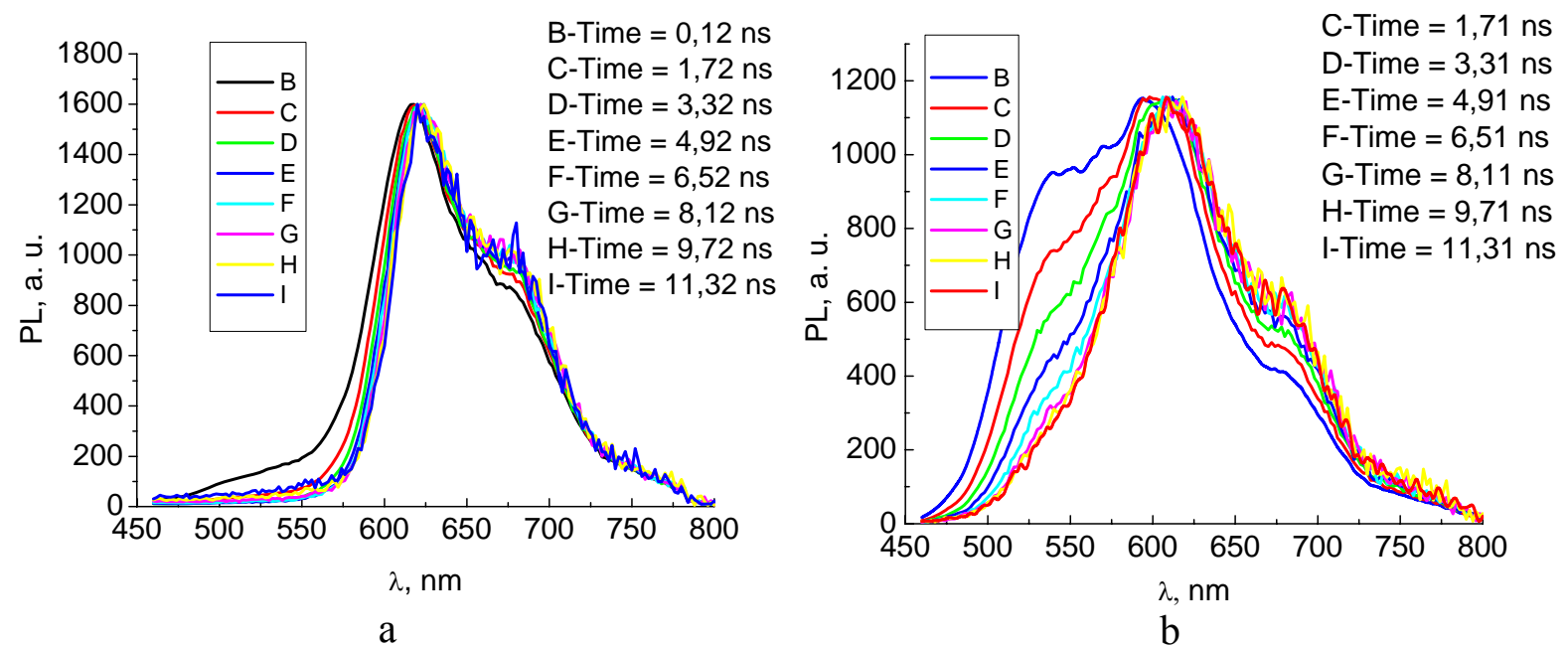

a

$$
\mathrm{b}
$$

Fig. 10. TRES of molecular solutions M-1 (a), M-2 (b) in the 5CBLC at $4.2 \mathrm{~K} . \lambda_{\text {ex }}=405 \mathrm{~nm}$. 


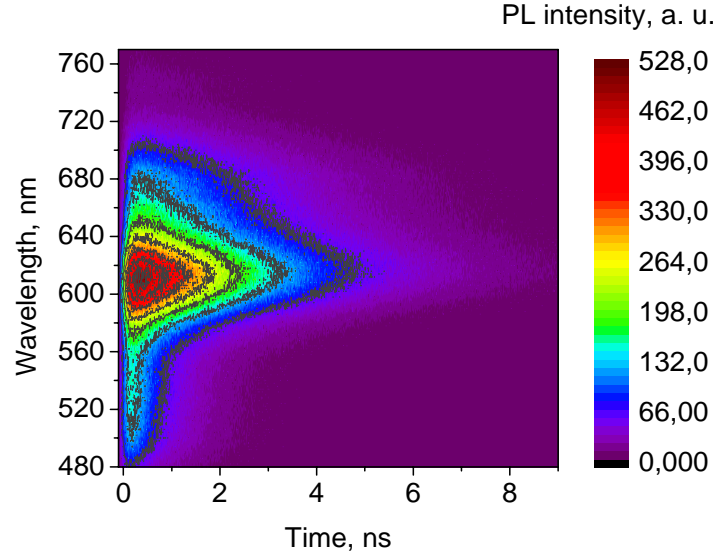

a

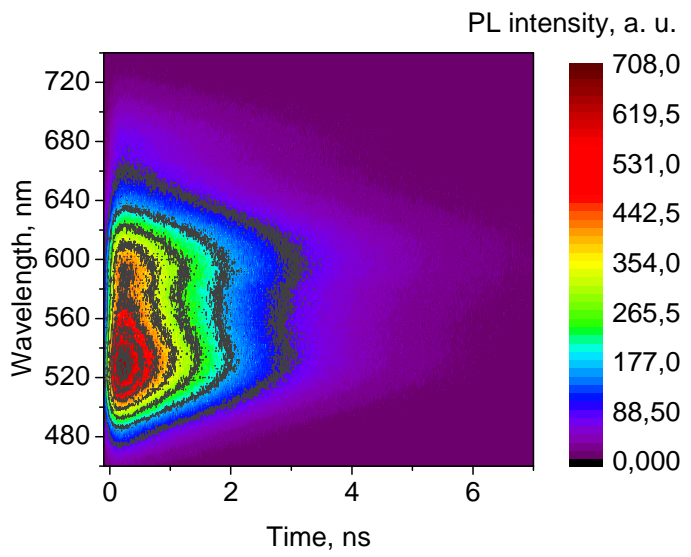

$\mathrm{b}$

Fig. 11. Map of TRES of molecular solutions M-1 (a), M-2 (b) in the 5CBLC at $4.2 \mathrm{~K} . \lambda_{e x}=405 \mathrm{~nm}$.

The fastest changes in the PL spectra of M-1 solution are observed at the initial time interval $t_{d}=0.1-1 \mathrm{~ns}$ after optical excitation at spectral ranges $480-550 \mathrm{~nm}$ and 640-760 $\mathrm{nm}$. There also is a slow PL component at interval $t_{d}=0.1-8 \mathrm{~ns}$, that prevails at the spectral range 550-650 $\mathrm{nm}$. The most intense PL of molecular solution M-1 in the 5CB LC is at the spectral range $550-650 \mathrm{~nm}$. The main difference of M-2 solution is a high intensity at the spectral range $460-550 \mathrm{~nm}$ at short delay times $\left(t_{d}=0.1-1 \mathrm{~ns}\right)$.

\section{CONCLUSIONS}

Analyzing optical properties of merocyanine dye molecules in different solvents, we summarize that torsional relaxations of $\mathrm{D}-\pi$-A complexes in low viscous solvents are frozen at $4.2 \mathrm{~K}$. The solvents with high viscosity delay torsional relaxations of merocyanine molecules also. Blocking of torsional relaxations significantly increases quantum yield and prolongs PL lifetime of M-1 and M-2 molecular solutions. The PL spectral properties (spectral shape and bands maxima) of molecular solutions $\mathrm{M}-1$ and M-2 in 5CB LC are similar. This phenomenon is explained by formation of merocyanine and liquid crystal molecular pairs and conformational adaptation of both types of merocyanine molecules to 5CB LC molecules. The concentration of molecular solutions is low $5 \cdot 10^{-5}$ merocyanine molecules per one LC molecule. Since the conformations of M-1 and M-2 molecules are almost identical, the $\pi$-electron conjugation of benzene ring and carbon chain is similar in both types of molecules and, thus, we see corresponding spectra.

\section{ACKNOWLEDGMENTS}

We appreciate the discussions with Anatoliy Verbitsky and the support of the Institute of Organic Chemistry, NAS of Ukraine.

\section{CONFLICT OF INTEREST}

The authors declare that there is no conflict of interest.

\section{AUTHORS' ORCID ID}

M.B. Malynovskyi (D) https://orcid.org/0000-0001-7309-6750

M.M. Sevryukova (D) https://orcid.org/0000-0002-4387-8345

Yu.P. Piryatinski (iD https://orcid.org/0000-0001-7225-8084 


\section{REFERENCES}

1. Sevryukova MM, Piryatinski YuP, Vasylyuk SV, Yashchuk VM, Viniychuk OO, Gerasov AO, et al. Cyanine-like and polyenic relaxation paths of merocyanine derivatives of malonodinitrile in the excited state detecting by low temperature time-resolved fluorescence. Ukr J Phys. 2012;57(8):812-23.

2. Maskevich AA, Stsiapura VI, Kuzmitsky VA, Kuznetsova IM, Povarova OI, Uversky VN, et al. Spectral properties of thioflavin $\mathrm{T}$ in solvents with different dielectric properties and in a fibril-incorporated form. J Proteome Res. 2007;6(4):1392-401. https://doi.org/10.1021/pr0605567

3. Stsiapura VI, Maskevich AA, Kuzmitsky VA, Turoverov KK, Kuznetsova IM. Computational study of thioflavin T torsional relaxation in the excited state. J Phys Chem A. 2007;111(22):4829-35.

https://doi.org/10.1021/jp070590o

4. Lisetski LN, Zavora LN, Kasian NA, Vashchenko OV, Panikarskaya VD. Cholesteric liquid crystals doped with molecules of organic scintillator materials. Mol Cryst Liq Cryst. 2009;510(1):106-15. https://doi.org/10.1080/15421400903058692

5. Piryatinski YuP, Sevryukova MM. Optical properties of $\pi$-conjugated donor-acceptor systems with controlled hyperpolarizability. Semiconductor Physics, Quantum Electronics and Optoelectronics. 2008;11(3):292-302.

6. Lemke R. Solvatochromie von $80 \mathrm{~m} \mu$ in verschiedenen Alkoholen bei Arylidenisophoron-Abkömmlingen [80 mu-Solvatochromy of Arylidenisophoron Derivatives in Different Alcohols]. Chemische Berichte. 1970;103(6):1894-9. [In German]. https://doi.org/10.1002/cber.19701030628

7. Lemke R. Knoevenagel-Kondensationen in Dimethylformamid [Knoevenagel condensations in dimethylformamide]. Synthesis. 1974;1974(5):359-61. [In German]. https://doi.org/10.1055/s-1974-23322

8. Sevryukova M, Piryatinski YuP. Dynamics of transfer of electron excitation in a donor-acceptor system with a carbon chain and ways of its relaxation. Semiconductor Physics Quantum Electronics and Optoelectronics. 2017 Jul;20(4):406-17. https://doi.org/10.15407/spqeo20.04.406

9. Fabian J, Zahradnic R. MO-LCAO calculations on polymethines. 6. PPP calculations on the vinylene shift of symmetric dyes. Wiss Z Tech Univ (Dresden). 1977;26:315-23.

10. Lutsyk P, Piryatinski Y, Kachkovsky O, Verbitsky A, Rozhin A. Unsymmetrical relaxation paths of the excited states in cyanine dyes detected by time-resolved fluorescence: polymethinic and polyenic forms. J Phys Chem A. 2017;121(43):8236-46. https://doi.org/10.1021/acs.jpca.7b08680

11. David C, Baeyens-Volant D. Absorption and fluorescence spectra of 4-cyanobiphenyl and 4'-alkyl- or 4'alkoxy-substituted liquid crystalline derivatives. Mol Cryst Liq Cryst. 1980;59(3-4):181-96. https://doi.org/10.1080/00268948008071422

12. Piryatinskiǔ YP, Yaroshchuk OV. Photoluminescence of pentyl-cyanobiphenyl in liquid-crystal and solidcrystal states. Optics and Spectroscopy. 2000;89(6):860-6. https://doi.org/10.1134/1.1335034

13. Petrov VF, Grebenkin MF, Ostrovskij BIC. Issledovanie struktury nematicheskoj fazy cyanoproizvodnykh piridina metodom rasseyaniya renthenovskih luchey [Study of the structure of the nematic phase of cyanide pyridine by X-ray scattering]. Kristallografiya. 1988;33(5):1194-201.

14. Piryatinskiı̌ YP, Yaroshchuk OV. Orientation of pentyl-cyanobiphenyl layers and variations in their luminescence spectra under UV irradiation. Optics and Spectroscopy. 2002;92(4):517-23. https://doi.org/10.1134/1.1473590 